\title{
Evaluation of materials of construction for the sulfuric acid decomposition section in the sulfur-iodine (S-I) cycle for hydrogen production: Some preliminary studies on selected materials
}

\author{
SACHIN TOMAR, ARPAN PAREEK, KISHORE KONDAMUDI and \\ SREEDEVI UPADHYAYULA* * \\ Department of Chemical Engineering, Indian Institute of Technology Delhi, New Delhi 110 016, India \\ E-mail: sreedevi@chemical.iitd.ac.in
}

MS received 18 February 2019; revised 24 May 2019; accepted 13 June 2019; published online 15 October 2019

\begin{abstract}
Water splitting by Sulfur-Iodine (S-I) cycle is one of the promising thermochemical processes for hydrogen production due to its high efficiency. The decomposition of $\mathrm{H}_{2} \mathrm{SO}_{4}$ to produce $\mathrm{SO}_{2}$ is the reaction with the highest energy demand in the $\mathrm{S}-\mathrm{I}$ cycle and it shows a large kinetic barrier. Sulfuric acid is highly corrosive and its endothermic decomposition needs elevated temperatures $\left(>800{ }^{\circ} \mathrm{C}\right)$. Henceforth, before the scale-up of the process plant there is a need to explore various materials of construction under very harsh acidic environments and phase changing conditions. Corrosion studies on some of the possible materials of construction (SS-304, SS-310, SS-316, Inconel-800, Alloy-20, Inconel-600, Incoloy-800H, Hastelloy C-276) were performed in detail and the most corrosion resistant material is suggested for the construction of sulfuric acid decomposition unit. The studies were performed at low temperatures $\left(60^{\circ} \mathrm{C}\right.$ and $120{ }^{\circ} \mathrm{C}$ ) as well as at high temperatures $\left(700{ }^{\circ} \mathrm{C}, 800{ }^{\circ} \mathrm{C}\right.$ and $\left.900{ }^{\circ} \mathrm{C}\right)$. The corrosion rates were determined using weight loss method at low as well as high temperature and by using electrochemical method at low temperature $\left(80^{\circ} \mathrm{C}\right)$. The phase changing condition was more severe and resulted in higher corrosion rate. Hastelloy C-276 showed the least corrosion rate.
\end{abstract}

Keywords. Sulfuric acid; S-I cycle; hydrogen; materials of construction; corrosion.

\section{Introduction}

The most attractive alternative to fossil fuel is hydrogen that is projected to become the energy carrier of the future because, from the perspective of zero emission energy production systems, hydrogen as a fuel will allow sustainable development. Unfortunately direct water dissociation is a non-practical way of obtaining hydrogen, due to the small value of the equilibrium constant for the reaction:

$\mathrm{H}_{2} \mathrm{O}(\mathrm{g}) \leftrightarrow \mathrm{H}_{2}(\mathrm{~g})+1 / 2 \mathrm{O}_{2}(\mathrm{~g})$

Thermochemical cycles are a suitable means of overcoming this problem. The so-called S-I thermochemical process originally proposed by General Atomic, ${ }^{1,2}$ turned out to be one of the most promising one. It operates at moderate-high temperatures $\left(25-900{ }^{\circ} \mathrm{C}\right)$ and it includes the following three reactions:

$$
\begin{aligned}
& \mathrm{I}_{2}(\mathrm{l})+\mathrm{SO}_{2}(\mathrm{~g})+2 \mathrm{H}_{2} \mathrm{O}(\mathrm{l}) \rightarrow 2 \mathrm{HI}(\mathrm{aq})+\mathrm{H}_{2} \mathrm{SO}_{4}(\mathrm{aq}) \\
& \mathrm{H}_{2} \mathrm{SO}_{4}(\mathrm{~g}) \rightarrow \mathrm{H}_{2} \mathrm{O}(\mathrm{g})+\mathrm{SO}_{2}(\mathrm{~g})+1 / 2 \mathrm{O}_{2}(\mathrm{~g}) \\
& 2 \mathrm{HI}(\mathrm{g}) \rightarrow \mathrm{H}_{2}(\mathrm{~g})+\mathrm{I}_{2}(\mathrm{~g})
\end{aligned}
$$

$\mathrm{H}_{2} \mathrm{SO}_{4}$ decomposition is the most endothermic reaction in the cycle and requires a temperature exceeding $800{ }^{\circ} \mathrm{C}$. Usually, sulfuric acid decomposition reaction is divided into two sub-reactions:

$$
\begin{aligned}
& \mathrm{H}_{2} \mathrm{SO}_{4}(\mathrm{~g}) \rightarrow \mathrm{H}_{2} \mathrm{O}(\mathrm{g})+\mathrm{SO}_{3}(\mathrm{~g}) \\
& \mathrm{SO}_{3}(\mathrm{~g}) \rightarrow \mathrm{SO}_{2}(\mathrm{~g})+1 / 2 \mathrm{O}_{2}(\mathrm{~g})
\end{aligned}
$$

Due to the high temperature operation and acidic environment, it is necessary to focus on the materials of construction of sulfuric acid decomposition section for the success of the process. Because of the importance of materials of construction in the process, researchers worked in this field to understand the effect of corrosion

*For correspondence 
on the materials. ${ }^{3-13}$ Edouard Asselin et al. ${ }^{14}$ used potentiodynamic polarization method as well as weight loss method to study the corrosion behavior of niobium $(\mathrm{Nb})$ in sulfuric acid at $75^{\circ} \mathrm{C}$ and $95^{\circ} \mathrm{C}$. They found that the higher concentration acid solution (40-80\%) resulted in less corrosion compared to lower concentration solutions (20-40\%). They concluded that $\mathrm{Nb}$ formed a passive film in concentrated sulfuric acid at temperature below $95^{\circ} \mathrm{C}$ and oxidation and dissolution were the factors responsible for corrosion. Nigam et al. ${ }^{15}$ investigated the electrochemical behavior of $\mathrm{Fe}$ 11.0Al-0.5, Fe-10.5Al-0.9C and Fe-10.5Al-0.8C-0.2Ce (in $\mathrm{wt} \%$ ). The Ce-alloyed iron aluminide exhibited superior surface film properties as compared to the iron aluminides due to the surface passivity and modified electrochemical behavior. McCafferty ${ }^{16}$ studied the validity and limitations of the Tafel extrapolation method for the determination of corrosion rates. They compared the experimental corrosion rates determined by the Tafel method and the non-electrochemical method (i.e. weight loss method) for titanium in boiling $1 \mathrm{M}$ sulfuric acid. They concluded that the Tafel region of the polarization curve can be extrapolated back to the steady-state open-circuit corrosion potential to give the open-circuit corrosion rate with some conditions applied.

In this study, an attempt was made to test the selected materials for the preliminary studies in the expected actual environment of the sulfuric acid decomposition in S-I cycle. Two corrosion measurement techniques were used: (a) Weight loss method and (b) Electrochemical method (Tafel slope method). There are some benefits and limitations of both the methods such as weight loss method is direct but time-consuming whereas electrochemical is a fast method. ${ }^{17}$ One of the limitations of electrochemical method is non-availability of the electrode which can work at higher temperature ranges. This limitation of electrochemical method sustains us to use it only for first category of the materials i.e., for materials which comes in contact with only liquid sulfuric acid. The aim of the study was to investigate the corrosion rates of the selected test coupons (SS-304, SS-310, SS-316, Inconel-800, Alloy-20, Incoloy-800H, Hastelloy $\mathrm{C}-276$ ) in sulfuric acid at liquid phase (low temperature, $60{ }^{\circ} \mathrm{C}$ and $120{ }^{\circ} \mathrm{C}$ ), vapor phase (high temperature, $700-900{ }^{\circ} \mathrm{C}$ ) as well as at phase changing conditions (high temperature, 700-900 ${ }^{\circ} \mathrm{C}$ ) using weight loss method and using electrochemical method at low temperature, $80{ }^{\circ} \mathrm{C}$ (SS-304, Alloy-20, Inconel600 , Incoloy- $800 \mathrm{H}$, Hastelloy C-276) and thus to suggest an appropriate material of construction for sulfuric acid decomposition section in S-I cycle.

\section{Experimental}

\subsection{Weight loss method}

In the weight loss method, test coupons (supplied by Sarbi Engineering \& WHG Pvt Ltd, India) were immersed in the sulfuric acid (95-98 wt\%, Fisher Scientific) at given operating conditions and measured the weight loss to evaluate the corrosion rate. The preparation and cleaning procedure of test coupons was followed according to the ASTM G1 guidelines and the method mentioned by Knapp in The Corrosion Handbook. ${ }^{18}$ In the low temperature test procedure, corrosion tests were conducted at temperatures, $60{ }^{\circ} \mathrm{C}$ and $120^{\circ} \mathrm{C}$. The setup used for this test was a glass beaker sealed with a rubber stopper in which the material specimen coupons were placed. The beaker was heated using water bath at $60{ }^{\circ} \mathrm{C}$ and oil bath was used at $120^{\circ} \mathrm{C}$. The specimens were kept suspended in sulfuric acid at the said temperature for a certain exposure time. After exposing the specimen in sulfuric acid for required exposure time, the specimen was treated with $25 \%$ sodium hydroxide $+200 \mathrm{~g} / \mathrm{l}$ zinc dust at boiling temperature (for iron alloys) or with $18 \%$ hydrochloric acid at ambient temperature (for nickel alloys). ${ }^{18}$ The duration of treatment is up to 5 min followed by mechanical scrubbing. Once it can be ensured that all the corroded parts of the specimen have been removed by the above described process then the specimen was weighed and this weight was compared with the initial weight of the specimen to calculate the weight loss in a particular exposure period and thus, the corrosion rate. Testing of the materials at higher temperatures i.e. at 700, 800 and $900{ }^{\circ} \mathrm{C}$ was carried out in the experimental setup as shown in Figure 1. Materials were hung at the three different locations in the quartz vessel, inside the sulfuric acid, above the sulfuric acid and at the surface (or interphase) of the sulfuric acid where materials are exposed to liquid phase, vapor phase and liquid plus vapor phase (mixed phase or phase change condition) respectively. The specimen coupon was hung in quartz vessel using teflon coated wire and the required temperature was achieved using electric heater. The vapors of sulfuric acid were collected in a separate jar with $\mathrm{NaOH}$ solution.

Equation 1 was used to find out the corrosion rates by weight loss method. ${ }^{14}$

$\mathrm{r}=8.76 * 10^{7}(\mathrm{~W} / \mathrm{A} * \mathrm{~T} * \rho)$

where, $r$ is average corrosion rate in $\mu \mathrm{m} / \mathrm{yr}, \mathrm{W}$ is the weight loss in grams, A is specimen area $\left(\mathrm{cm}^{2}\right)$, $\mathrm{T}$ is the exposure time in hours, and $\rho$ is the density of the 

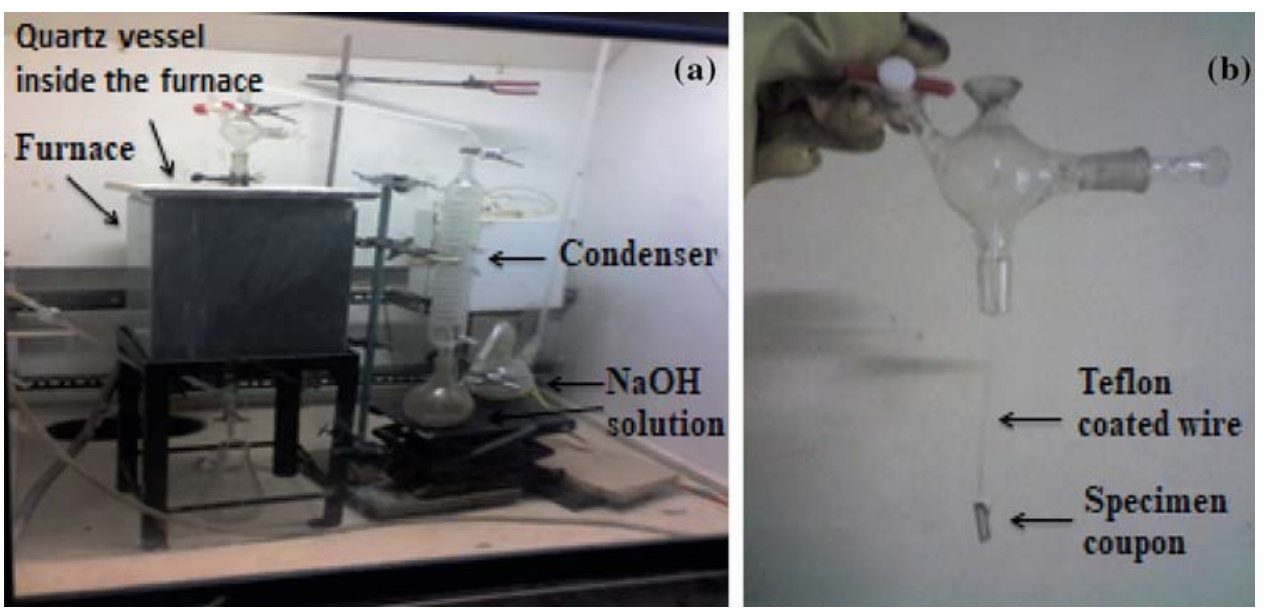

Figure 1. (a) Experimental setup. (b) Specimen coupon.

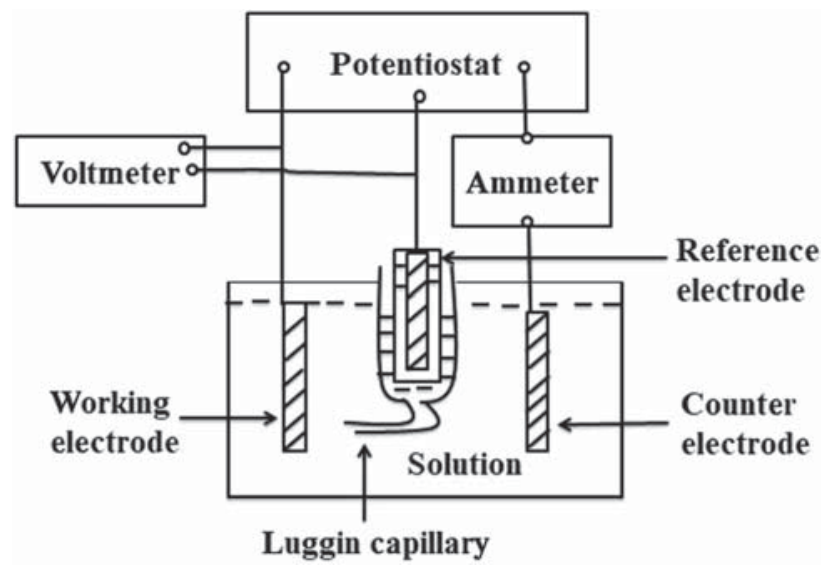

Figure 2. Schematic diagram of the apparatus for electrochemical method.

material. Each test was performed in triplicate and data showed reproducibility within 10\%. Average values were obtained and used in the calculations.

\subsection{Electrochemical method}

Electrochemical method is also known as Tafel slope method. In this method corrosion rate analysis was done by the extrapolation of Tafel slope. Experiments were conducted using the conventional three-electrode system as shown in Figure 2. The electrochemical cell contains a glass cell module, a graphite counter electrode an external $\mathrm{Ag} / \mathrm{AgCl}$ reference electrode (saturated $\mathrm{KCl}$ fill solution), and the working electrode (WE). The potential scan rate was $2 \mathrm{mVs}^{-1}$ and nitrogen was used for deaerating the system. Equation 2 relates corrosion rate $(\mu \mathrm{m} / \mathrm{yr})$ to corrosion current density, $\mathrm{i}_{\text {corr }}\left(\mu \mathrm{A} / \mathrm{cm}^{2}\right)$ through Faraday's law. ${ }^{14}$ $\mathrm{r}=3.28 *\left(\left(\mathrm{M} * \mathrm{i}_{\text {corr }}\right) / \mathrm{n} * \rho\right)$

where, $\mathrm{M}$ is the atomic weight of the metal, $\mathrm{n}$ is the number of electrons exchanged for the reaction, and $\rho$ is the density of the metal.

\section{Results and Discussion}

\subsection{Corrosion testing using weight loss method}

The calculated corrosion rates using weight loss method are shown in Table 1 . The given temperature range was below the boiling point of the sulfuric acid. Sulfuric acid $(95 \mathrm{wt} \%)$ reacted with the materials in its liquid state. Time of exposure was kept $4 \mathrm{~h}$ for the materials react at $60{ }^{\circ} \mathrm{C}$ whereas it was decreased to $2 \mathrm{~h}$ with the increase in the temperature. It was observed that corrosion rate increased with increase in temperature. At both the temperatures SS-310 shown the highest corrosion rate $\left(2.53 * 10^{3} \mu \mathrm{m} / \mathrm{yr}\right.$ at $60{ }^{\circ} \mathrm{C}$ and $5.32 * 10^{3}$ $\mu \mathrm{m} / \mathrm{yr}$ at $120^{\circ} \mathrm{C}$ ) whereas Inconel-800 exhibited lowest corrosion rate $\left(0.71 * 10^{3} \mu \mathrm{m} / \mathrm{yr}\right.$ at $60{ }^{\circ} \mathrm{C}$ and $3.47 * 10^{3} \mu \mathrm{m} / \mathrm{yr}$ at $\left.120{ }^{\circ} \mathrm{C}\right)$. SS-310, SS-316 showed fine pits formation and rough surface whereas discoloration occurred on the surface of Inconel-800 and Hastelloy C-276 after corrosion test.

With the same materials (SS-304, SS-316 and Inconel$800)$ experiments were conducted at the higher temperatures $\left(700{ }^{\circ} \mathrm{C}, 800{ }^{\circ} \mathrm{C}\right.$ and $\left.900{ }^{\circ} \mathrm{C}\right)$ as reported in Table 2, Table 3 and Table 4. Studies have been conducted at higher temperatures because the similar environment is required for sulfuric acid decomposition in S-I cycle. At these conditions sulfuric acid reacted with the materials in both phases i.e. vapors only and liquid plus vapor (mixed phase). At the elevated temperatures, time of exposure was $1 \mathrm{~h}$. According to Table 2, 
Table 1. Corrosion rates of SS-310, SS-316, SS-304 and Inconel-800, Hastelloy C-276.

\begin{tabular}{llccccc}
\hline S1. no. & \multicolumn{1}{c}{ Materials } & $\begin{array}{c}\text { Temperature } \\
\left({ }^{\circ} \mathrm{C}\right)\end{array}$ & $\begin{array}{c}\text { Exposure area } \\
\left(\mathrm{cm}^{2}\right)\end{array}$ & $\begin{array}{c}\text { Time of exposure } \\
(\mathrm{h})\end{array}$ & $\begin{array}{c}\text { Weight loss } \\
(\mathrm{g})\end{array}$ & $\begin{array}{c}\text { Corrosion rate } \\
(\mu \mathrm{m} / \mathrm{yr}) * 10^{3}\end{array}$ \\
\hline 1 & SS-310 & 60 & 3.35 & 4 & 0.0032 & 2.53 \\
2 & SS-316 & 60 & 7.45 & 4 & 0.0021 & 0.74 \\
3 & SS-304 & 60 & 5.04 & 4 & 0.0037 & 1.95 \\
4 & Inconel-800 & 60 & 4.62 & 4 & 0.0013 & 0.71 \\
5 & Hastelloy C-276 & 60 & 4.62 & 4 & 0.0006 & 0.32 \\
6 & SS-310 & 120 & 3.03 & 2 & 0.0028 & 5.32 \\
7 & SS-316 & 120 & 7.74 & 2 & 0.0057 & 4.07 \\
8 & SS-304 & 120 & 5.32 & 2 & 0.0043 & 4.46 \\
9 & Inconel-800 & 120 & 4.94 & 2 & 0.0032 & 3.47 \\
10 & Hastelloy C-276 & 120 & 4.94 & 2 & 0.0025 & 2.91 \\
\hline
\end{tabular}

Table 2. Corrosion rates of SS-304.

\begin{tabular}{llccccc}
\hline S1. no & $\begin{array}{c}\text { Nature of the acid } \\
\text { environment }\end{array}$ & $\begin{array}{c}\text { Temperature } \\
\left({ }^{\circ} \mathrm{C}\right)\end{array}$ & $\begin{array}{c}\text { Exposure } \\
\text { time }(\mathrm{h})\end{array}$ & $\begin{array}{c}\text { Exposure area } \\
\left(\mathrm{cm}^{2}\right)\end{array}$ & $\begin{array}{c}\text { Weight loss } \\
(\mathrm{mg})\end{array}$ & $\begin{array}{c}\text { Corrosion rate } \\
(\mu \mathrm{m} / \mathrm{yr}) * 10^{3}\end{array}$ \\
\hline 1 & Vapor & 700 & 1 & 2.452 & 15.79 & 7.05 \\
2 & Vapor & 800 & 1 & 2.787 & 21.23 & 8.34 \\
3 & Vapor & 900 & 1 & 3.045 & 22.05 & 7.93 \\
4 & Liquid and vapor & 700 & 1 & 2.452 & 24.23 & 10.82 \\
5 & Liquid and vapor & 800 & 1 & 2.787 & 48.27 & 18.96 \\
6 & Liquid and vapor & 900 & 1 & 3.045 & 65.13 & 23.42 \\
\hline
\end{tabular}

Table 3. Corrosion rates of SS-316.

\begin{tabular}{llccccc}
\hline S1. no. & $\begin{array}{c}\text { Nature of the acid } \\
\text { environment }\end{array}$ & $\begin{array}{c}\text { Temperature } \\
\left({ }^{\circ} \mathrm{C}\right)\end{array}$ & $\begin{array}{c}\text { Exposure } \\
\text { time }(\mathrm{h})\end{array}$ & $\begin{array}{c}\text { Exposure area } \\
\left(\mathrm{cm}^{2}\right)\end{array}$ & $\begin{array}{c}\text { Weight loss } \\
(\mathrm{mg})\end{array}$ & $\begin{array}{c}\text { Corrosion rate } \\
(\mu \mathrm{m} / \mathrm{yr}) * 10^{3}\end{array}$ \\
\hline 1 & Vapor & 700 & 1 & 4.632 & 16.64 & 6.45 \\
2 & Vapor & 800 & 1 & 3.875 & 21.78 & 7.74 \\
3 & Vapor & 900 & 1 & 4.447 & 21.11 & 5.93 \\
4 & Liquid and vapor & 700 & 1 & 4.632 & 23.29 & 8.84 \\
5 & Liquid and vapor & 800 & 1 & 3.875 & 44.48 & 16.98 \\
6 & Liquid and vapor & 900 & 1 & 4.447 & 51.18 & 21.12 \\
\hline
\end{tabular}

corrosion rate of SS-304 was $7.05 * 10^{3} \mu \mathrm{m} / \mathrm{yr}$ at $700{ }^{\circ} \mathrm{C}$ and $7.93 * 10^{3} \mu \mathrm{m} / \mathrm{yr}$ at $900{ }^{\circ} \mathrm{C}$ in vapor phase whereas it was increased to $10.82 * 10^{3} \mu \mathrm{m} / \mathrm{yr}$ and $23.42 * 10^{3} \mu \mathrm{m} / \mathrm{yr}$ at $700{ }^{\circ} \mathrm{C}$ and $900{ }^{\circ} \mathrm{C}$ respectively in mixed phase. Figure 3 shows one-hour exposure of SS304 to the acidic environment at $800{ }^{\circ} \mathrm{C}$. It was observed that more corrosion occurred on the surface which was exposed to phase changing condition (mixed phase). As per Table 3, SS-316 was treated with sulfuric acid in both phases at higher temperature range, $700-900{ }^{\circ} \mathrm{C}$. At the same temperature, $700{ }^{\circ} \mathrm{C}$, corrosion rates were $6.45 * 10^{3} \mu \mathrm{m} / \mathrm{yr}$ and $8.84 * 10^{3}$ in liquid and mixed phase respectively. There was an increment in the corrosion rate at $900{ }^{\circ} \mathrm{C}$ in both the phases. The same behavior in corrosion rates was observed in Inconel-800 in both the phases in the temperature range of 700-900 ${ }^{\circ} \mathrm{C}$ as shown in Table 4. Corrosion rates varied from
$2.22 * 10^{3} \mu \mathrm{m} / \mathrm{yr}$ to $1.62 * 10^{3} \mu \mathrm{m} / \mathrm{yr}$ in vapor phase in the temperature range of $700-900{ }^{\circ} \mathrm{C}$ whereas in the mixed phase corrosion rates varied from $4.08 * 10^{3}$ to $4.51 * 10^{3} \mu \mathrm{m} / \mathrm{yr}$ in the same temperature range. It was noticed that with increase in the temperature corrosion rate was increasing. This might be due to the increase in oxygen diffusion at higher temperature such that more oxygen reaches the surface of the material by decreasing the viscosity of the acid and corrode the surface. In the mixed phase condition, major dissolution of metal and scratches were observed in SS-304 and SS-316, whereas discoloration of the surface was observed in Inconel-800.

Table 5 shows corrosion rates of Alloy 20, Incoloy $800 \mathrm{H}$ and Hastelloy C-276 in $98 \mathrm{wt} \%$ sulfuric acid at phase changing conditions. Materials were tested at the temperature range of $700-900{ }^{\circ} \mathrm{C}$. Corrosion rates of Alloy 20 were $6.28 * 10^{3} \mu \mathrm{m} / \mathrm{yr}$ and $6.82 * 10^{3} \mu \mathrm{m} / \mathrm{yr}$ 
Table 4. Corrosion rates of Inconel-800.

\begin{tabular}{llccccc}
\hline Sl. no & $\begin{array}{c}\text { Nature of the acid } \\
\text { environment }\end{array}$ & $\begin{array}{c}\text { Temperature } \\
\left({ }^{\circ} \mathrm{C}\right)\end{array}$ & $\begin{array}{c}\text { Exposure } \\
\text { time }(\mathrm{h})\end{array}$ & $\begin{array}{c}\text { Exposure area } \\
\left(\mathrm{cm}^{2}\right)\end{array}$ & $\begin{array}{c}\text { Weight loss } \\
(\mathrm{mg})\end{array}$ & $\begin{array}{c}\text { Corrosion rate } \\
(\mu \mathrm{m} / \mathrm{yr}) * 10^{3}\end{array}$ \\
\hline 1 & Vapor & 700 & 1 & 2.867 & 5.79 & 2.22 \\
2 & Vapor & 800 & 1 & 3.257 & 10.18 & 3.43 \\
3 & Vapor & 900 & 1 & 3.621 & 5.34 & 1.62 \\
4 & Liquid and vapor & 700 & 1 & 2.867 & 10.65 & 4.08 \\
5 & Liquid and vapor & 800 & 1 & 3.257 & 13.26 & 4.47 \\
6 & Liquid and vapor & 900 & 1 & 3.621 & 14.87 & 4.51 \\
\hline
\end{tabular}
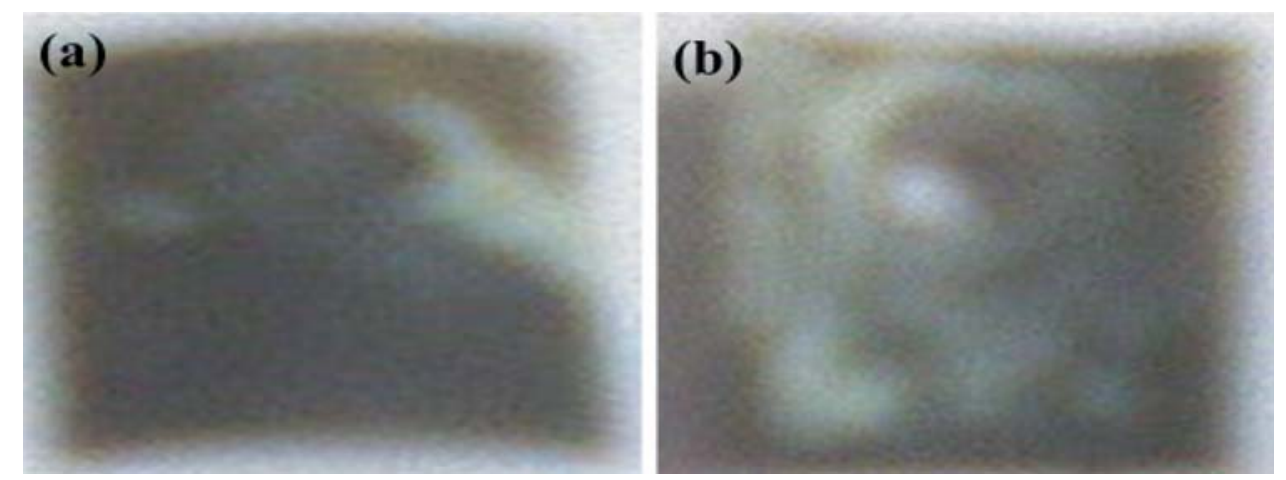

Figure 3. SS-304 after exposure to (a) vapor phase and (b) phase changing conditions.

at $700{ }^{\circ} \mathrm{C}$ and $900{ }^{\circ} \mathrm{C}$, respectively after $4 \mathrm{~h}$ of exposure. More weight loss was found at $800{ }^{\circ} \mathrm{C}$ that resulted in a higher corrosion rate. Figure 4 shows the exposure of alloy 20 at different phases. Discoloration of the surface was observed. Dissolution and pitting were observed in the sample exposed to the phase changing condition as shown in Figure 4(c). Incoloy $800 \mathrm{H}$ was exposed for $1 \mathrm{~h}$ in the temperature range of $700-900{ }^{\circ} \mathrm{C}$. Corrosion rate was found the lowest $\left(4.82 * 10^{3} \mu \mathrm{m} / \mathrm{yr}\right)$ at $700{ }^{\circ} \mathrm{C}$ which increased with the temperature, $800{ }^{\circ} \mathrm{C}$ $\left(5.96 * 10^{3} \mu \mathrm{m} / \mathrm{yr}\right)$ and decreased with further increase in temperature, $5.42 * 10^{3} \mu \mathrm{m} / \mathrm{yr}$ at $900{ }^{\circ} \mathrm{C}$. Hastelloy $\mathrm{C}-276$ was exposed in the phase changing condition for $4 \mathrm{~h}$. Higher weight loss $(37.85 \mathrm{mg})$ was found at $800{ }^{\circ} \mathrm{C}$ in comparison to $700{ }^{\circ} \mathrm{C}(35.24 \mathrm{mg})$ and $900{ }^{\circ} \mathrm{C}$
(30.13 mg) resulted in higher rate of corrosion at $800{ }^{\circ} \mathrm{C}$. Increase of $\mathrm{Ni}$ content of the alloy helps in the reduction of corrosion in the oxidizing atmosphere. ${ }^{19}$ Corrosion rates decreased when temperature increased from $800{ }^{\circ} \mathrm{C}$ to $900{ }^{\circ} \mathrm{C}$ in some materials. It might be due to the passivation phenomenon which prevents corrosion by creating a protecting cover against the corrosion and reduces the further oxidation of the material. Another possible reason for less corrosion is low oxygen solubility at higher temperature. Pitting and dissolution of metal were observed in Alloy-20 and scratches on the surface were visible on the surface of Incoloy $800 \mathrm{H}$. Uniform thin layer was observed on the surface of Hastelloy C-276 which might help in the reduction of corrosion further.

Table 5. Corrosion rates of Alloy 20, Incoloy 800H and Hastelloy C-276.

\begin{tabular}{llccccc}
\hline S1. no & \multicolumn{1}{c}{ Material } & $\begin{array}{c}\text { Temperature } \\
\left({ }^{\circ} \mathrm{C}\right)\end{array}$ & $\begin{array}{c}\text { Exposure time } \\
(\mathrm{h})\end{array}$ & $\begin{array}{c}\text { Exposure area } \\
\left(\mathrm{cm}^{2}\right)\end{array}$ & $\begin{array}{c}\text { Weight loss } \\
(\mathrm{mg})\end{array}$ & $\begin{array}{c}\text { Corrosion rate } \\
(\mu \mathrm{m} / \mathrm{yr}) * 10^{3}\end{array}$ \\
\hline 1 & Alloy 20 & 700 & 4 & 10.128 & 61.23 & 6.28 \\
2 & Alloy 20 & 800 & 4 & 10.128 & 71.27 & 7.09 \\
3 & Alloy 20 & 900 & 4 & 10.128 & 65.13 & 6.82 \\
4 & Incoloy 800H & 700 & 1 & 9.875 & 24.23 & 4.82 \\
5 & Incoloy 800H & 800 & 1 & 9.875 & 65.13 & 5.96 \\
6 & Incoloy 800H & 900 & 1 & 9.875 & 48.27 & 5.42 \\
7 & Hastelloy C-276 & 700 & 4 & 10.104 & 35.24 & 3.82 \\
8 & Hastelloy C-276 & 800 & 4 & 10.104 & 37.85 & 3.96 \\
9 & Hastelloy C-276 & 900 & 4 & 10.104 & 30.13 & 3.42 \\
\hline
\end{tabular}



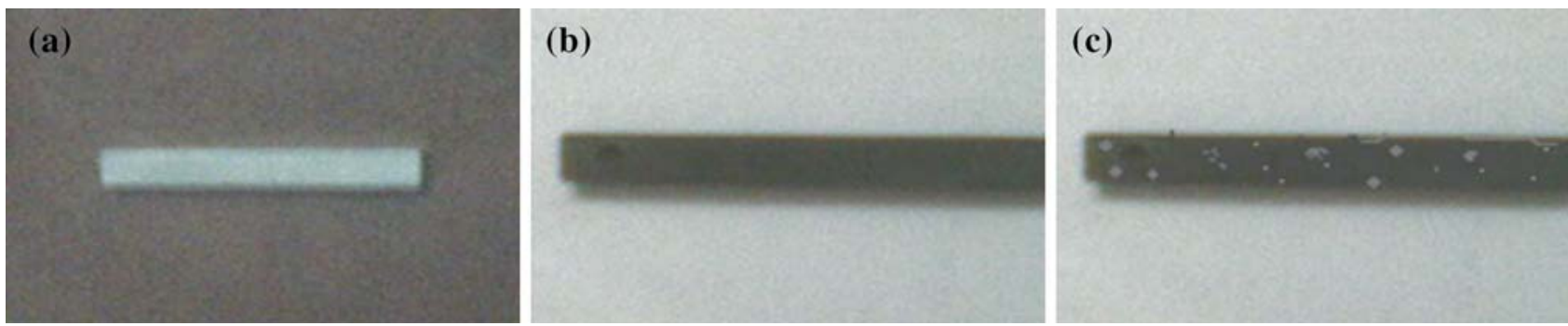

Figure 4. Alloy 20 (a) Fresh (b) after $4 \mathrm{~h}$ of exposure to vapour of sulfuric acid (c) after $4 \mathrm{~h}$ of exposure to phase changing conditions in sulfuric acid.

\subsection{Corrosion testing using Electrochemical method}

Tafel extrapolation method was used to find out the corrosion potential $\left(\mathrm{E}_{\mathrm{corr}}\right)$ and corrosion current density $\left(i_{\text {corr }}\right)$. Intersection point of Tafel slope after extrapolation represents the $\mathrm{E}_{\mathrm{corr}}$ and $\mathrm{i}_{\text {corr }}$ at the corresponding axis. Tests were performed in $98 \mathrm{wt} \%$ sulfuric acid at $80{ }^{\circ} \mathrm{C}$. Polarization curves of SS-304 and Alloy 20 are shown in Figure 5(a) and Figure 5(b) respectively. Corrosion rates were $13.3 * 10^{3} \mu \mathrm{m} / \mathrm{yr}$ and $19.7 * 10^{3} \mu \mathrm{m} / \mathrm{yr}$ of SS-304 and Alloy 20
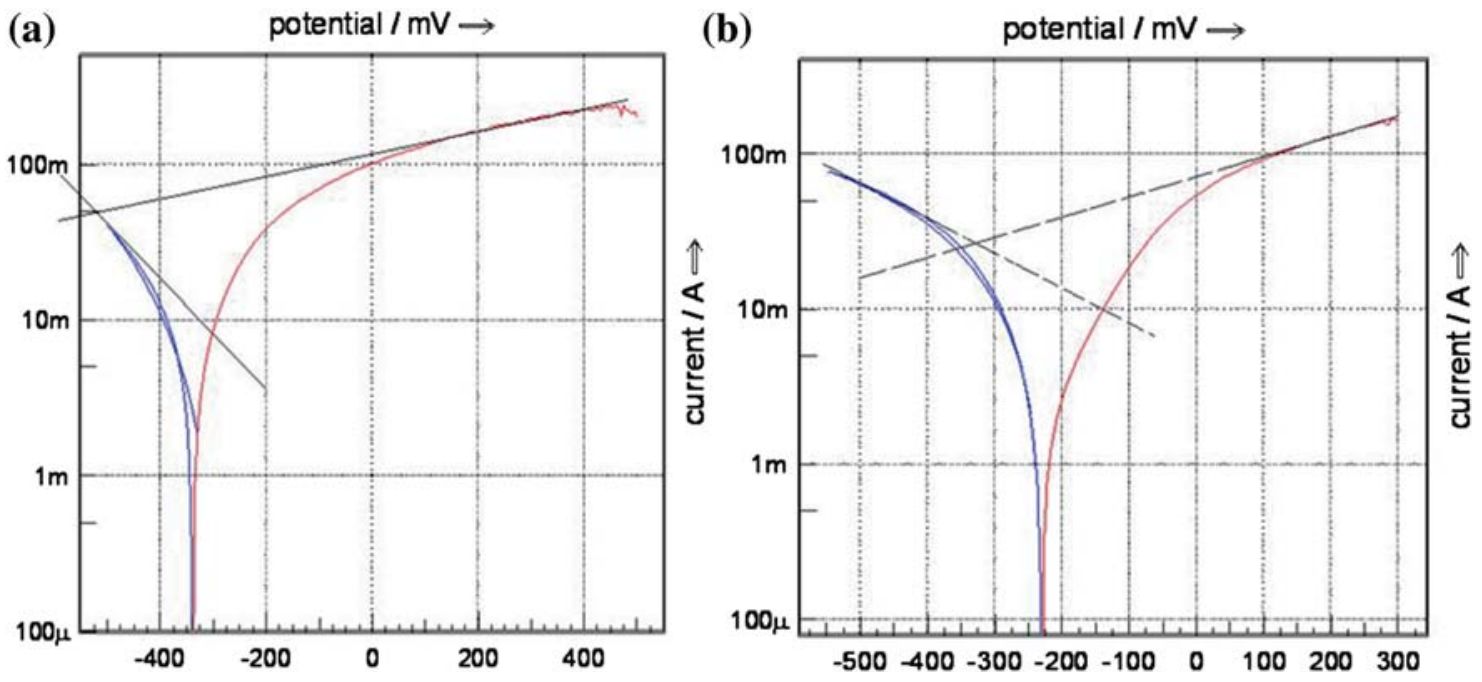

Figure 5. Polarization curves of (a) SS-304 (b) Alloy 20.

(a)

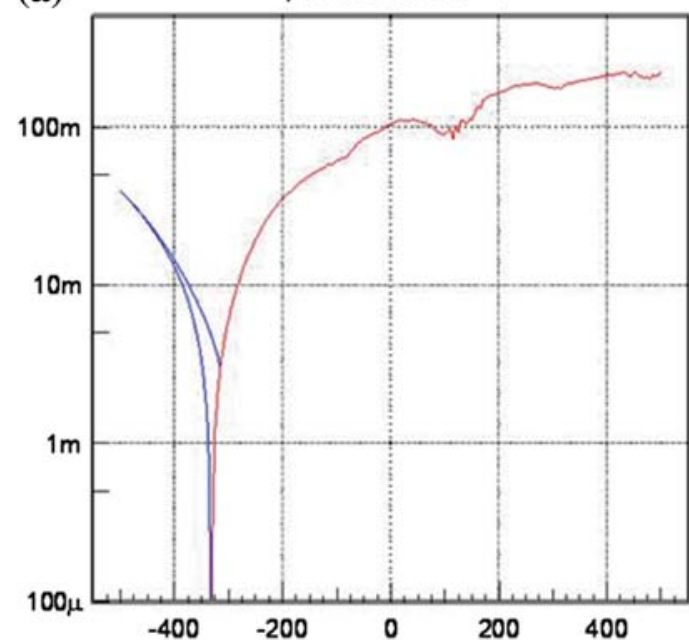

(b)

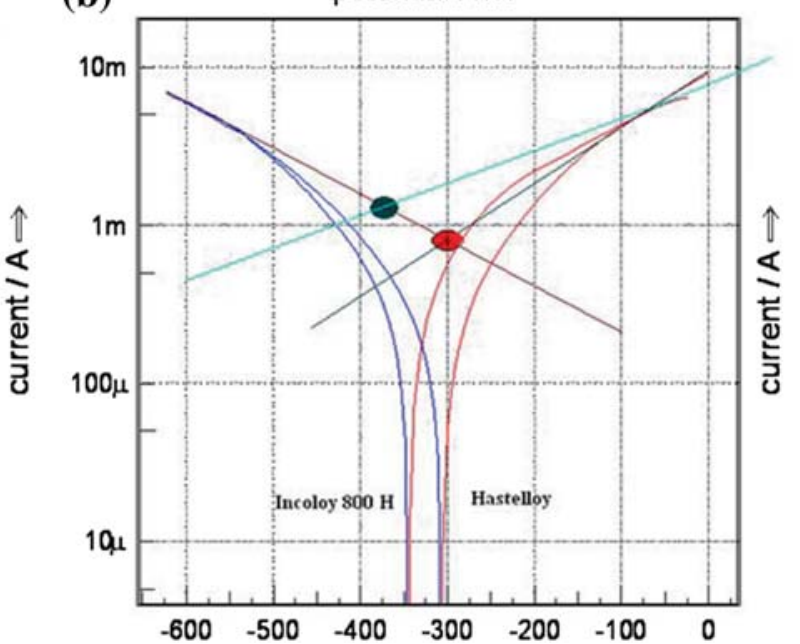

Figure 6. Polarization curves of (a) Inconel 600 (b) Incoloy $800 \mathrm{H}$ and Hastelloy C-276. 
Table 6. Data obtained from Polarization curves based on the calculated slopes.

\begin{tabular}{lccccccc}
\hline Material & Polarization current in $(\mathrm{mA})$ & $\mathrm{E}_{\text {corr }}(\mathrm{mV})$ & $\beta \mathrm{a}$ & $\beta \mathrm{c}$ & $\mathrm{B}$ & $\mathrm{R}_{\mathrm{P}}$ & Corrosion rate $(\mu \mathrm{m}$ per year) \\
\hline SS-304 & 70 & -575 & 0.1 & 0.533 & 0.036 & 0.15 & $13.3 * 10^{3}$ \\
Alloy 20 & 40 & -475 & 0.15 & 0.35 & 0.045 & 0.25 & $19.7 * 10^{3}$ \\
Incoloy 800 H & 1.5 & -425 & 0.2 & 0.22 & 0.046 & 0.5 & $0.42 * 10^{3}$ \\
Hastelloy C-276 & 0.9 & -300 & 0.2 & 0.4 & 0.057 & 0.5 & $0.58 * 10^{3}$ \\
\hline
\end{tabular}

* Sample calculation of corrosion rate from Tafel slope:

$\mathrm{i}_{\text {corr }}=10^{6} * \mathrm{~B} / \mathrm{R}_{\mathrm{p}} \mu \mathrm{Acm}^{-2}$

$\mathrm{B}$ is the Stern-Geary coefficient and $\mathrm{R}_{\mathrm{P}}$ is the polarization resistance in ohm- $\mathrm{cm}^{2}$. The polarization resistance $(R p)$ is defined as the slope of a potential (E) vs. Current density (I) plot in the vicinity of the corrosion potential $\left(\mathrm{E}_{\text {corr }}\right)$ or when the applied current is nearing zero. For Incoloy $800 \mathrm{H}$ the coefficient $B$ is calculated as

$$
\begin{aligned}
& \mathrm{B}=(\beta \mathrm{a} * \beta \mathrm{c}) / 2.303 *(\beta \mathrm{a}+\beta \mathrm{c})=[(0.2) *(0.22)] /[(2.303) *(0.42)]=0.044 / 0.967=0.046 \\
& \mathrm{i}_{\text {corr }}=(\beta \mathrm{a} \beta \mathrm{c}) /\left(2.3 \mathrm{R}_{\mathrm{P}}(\beta \mathrm{a}+\beta \mathrm{c})\right)=(0.2 * 0.22) /(2.3 * 0.5 *(0.2+0.22))=0.091 \mathrm{~A} / \mathrm{cm}^{2} \\
& \text { Corrosion rate }(\mathrm{CR}) \text { in } \mu \mathrm{m} / \mathrm{yr}=\left(\mathrm{M} \mathrm{i}_{\text {corr }}\right) /(\mathrm{n} \mathrm{d} \mathrm{F})
\end{aligned}
$$

where, $\mathrm{M}$ is the atomic weight of the metal; $\mathrm{n}$ is the charge number which specifies the number of electrons exchanged in the dissolution reaction; $\mathrm{F}$ is the Faraday constant; $\mathrm{d}$ is the density of the metal.

For Incoloy $800 \mathrm{H}, \mathrm{CR}=\left(\mathrm{M} \mathrm{i}_{\text {corr }}\right) /(\mathrm{n} \mathrm{d} \mathrm{F})=(0.091)(4615)=0.42 \times 10^{3} \mu \mathrm{m} / \mathrm{yr}$.

respectively. Figure 6(a) shows the polarization curve of Inconel 600. The anodic current does not show Tafel behavior. It might be due to the formation of some unknown complex of nickel at some particular potential values. Tafel slope method cannot be applied here. There might be a formation of metastable pits represented by the fluctuation in the curve which make it unsuitable as a choice for material of construction for sulfuric acid decomposition section. Figure 6(b) shows the polarization curve of Incoloy $800 \mathrm{H}$ and Hastelloy C-276. It was found that Hastelloy and Incoloy $800 \mathrm{H}$ have the lowest corrosion rate among the tested alloys using electrochemical method as shown in Table 6.

\section{Conclusions}

The highly endothermic sulfuric acid decomposition in S-I cycle demands high temperatures. Hence, identifying various suitable materials of construction to suit the liquid phase, phase changing and high temperature vapor phase conditions are important for the overall process development and scale-up. The sulfuric acid environment is extremely corrosive and the severity increases with temperature, and it might be due to high oxygen diffusivity leading to more oxygen at the surface resulting in high corrosion rate. In the present work, SS-304, SS-310, SS-316, Inconel-800, Alloy-20, Inconel 600, Incoloy-800H, and Hastelloy C-276 material test coupons were exposed to low $\left(60-120{ }^{\circ} \mathrm{C}\right)$ as well as high temperature $\left(700-900{ }^{\circ} \mathrm{C}\right.$ ) range as required during the sulfuric acid decomposition reaction. Corrosion rates were determined using both weight loss method and electrochemical method (at $80^{\circ} \mathrm{C}$ ). At higher temperatures (from 800 to $900{ }^{\circ} \mathrm{C}$ ) corrosion rate decreased slightly in some test coupons which may be attributed to low oxygen solubility at higher temperature. Formation of continuous layers by passivation acted as protective layer against further corrosion in some coupons whereas pitting and dissolution were responsible for higher corrosion rate. The exposure of the test coupons to sulfuric acid phase changing conditions resulted in high corrosion rates. Among the tested materials, Hastelloy C-276 shown good resistance against the corrosion and Inconel-800 exhibited the lowest corrosion rate of $0.71 * 10^{3} \mu \mathrm{m} /$ yr at $60{ }^{\circ} \mathrm{C}$ and $3.47 * 10^{3} \mu \mathrm{m} / \mathrm{yr}$ at $120{ }^{\circ} \mathrm{C}$ in the liquid phase conditions which make them a suitable choice for the materials of construction for sulfuric decomposition section.

\section{Acknowledgement}

The authors thankfully acknowledge the help of Dr. Jaya Raja Rao, Scientist, BPCL R\&D. Greater Noida for the corrosion testing equipment facility. Funding from ONGC Energy Centre is thankfully acknowledged.

\section{References}

1. Norman J, Mysels K, Sharp R and Williamson D 1982 Studies of the sulfur-iodine thermochemical watersplitting cycle Int. J. Hydrogen Energy 7545 
2. Kondamudi K and Upadhyayula S 2012 Kinetic studies of sulfuric acid decomposition over $\mathrm{Al}-\mathrm{Fe}_{2} \mathrm{O}_{3}$ catalyst in the sulfur-iodine cycle for hydrogen production Int. J. Hydrogen Energy 373586

3. High efficiency generation of hydrogen fuels using nuclear power. https://www.osti.gov/servlets/purl/ 814014. Accessed on 23 June 2018.

4. Roth M and Knoche K F 1989 Thermochemical water splitting through direct $\mathrm{HI}$-decomposition from $\mathrm{H}_{2} \mathrm{O}$ / $\mathrm{HI} / \mathrm{I}_{2}$ solutions Int. J. Hydrogen Energy 14545

5. Materials development for sulfur-iodine thermochemical hydrogen production. https://fusion.gat.com/pubsext/miscpubs/A25750.pdf. Accessed on 28 June 2018

6. Mahato B K, Cha C Y and Shemilt L W 1980 Unsteady state mass transfer coefficients controlling steel pipe corrosion under isothermal flow conditions Corros. Sci. 20421

7. Wong B, Buckingham R T, Brown L C, Russ B E, Besenbruch G E, Kaiparambil A, Santhanakrishnan R and Roy A 2007 Construction materials development in sulfur-iodine thermochemical water-splitting process for hydrogen production Int. J. Hydrogen Energy 32 497

8. Jegdic B, Drazic D M and Popic J P 2006 Corrosion potential of 304 stainless steel in sulfuric acid J. Serb. Chem. Soc. 71543

9. Porisini F C 1989 Selection and evaluation of materials for the construction of a pre-pilot plant for thermal decomposition of sulphuric acid Int. J. Hydrogen Energy 14267

10. Flitt H J and Schweinsberg D P 2005 Evaluation of corrosion rate from polarisation curves not exhibiting a Tafel region Corros. Sci. 473034
11. Sakurai M, Nakajima H, Onuki K, Ikenoya $\mathrm{K}$ and Shimizu S 1999 Preliminary process analysis for the closed cycle operation of the iodine-sulfur thermochemical hydrogen production process Int. J. Hydrogen Energy 24603

12. Kubo S, Futakawa M, Ioka I, Onuki K and Akihisa $Y$ 2013 Corrosion resistance of structural materials in high-temperature aqueous sulfuric acids in thermochemical water-splitting iodine-sulfur process Int. J. Hydrogen Energy 386577

13. Li Y, Ives M B and Coley K S 2006 Corrosion potential oscillation of stainless steel in concentrated sulphuric acid: I. Electrochemical aspects Corros. Sci. 481560

14. Asselin E, Ahmed T M and Alfantazi 2007 A corrosion of niobium in sulphuric and hydrochloric acid solutions at 75 and $95{ }^{\circ} \mathrm{C}$ Corros. Sci. 49694

15. Nigam A K, Balasubramaniam R, Bhargava $S$ and Baligidad R G 2006 Electrochemical impedance spectroscopy and cyclic voltammetry study of carbonalloyed iron aluminides in sulfuric acid Corros. Sci. 48 1666

16. McCafferty E 2005 Validation of corrosion rates measured by the Tafel extrapolation method Corros. Sci. 473202

17. Zou Y, Wang J and Zheng Y Y 2011 Electrochemical techniques for determining corrosion rate of rusted steel in seawater Corros. Sci. 53208

18. Knapp B B 1948 The Corrosion Handbook H H Uhlig (Ed.) (New York: Wiley) p.1077

19. Alharthi N, Sherif E-S M, Abdo H S and Abedin S Z L 2017 Effect of nickel content on the corrosion resistance of iron-nickel alloys in concentrated hydrochloric acid pickling solutions Adv. Mat. Sci. Eng. 61 